\title{
Development of touristic village and creative industry in improving social welfare at Wukirsari Village, Imogiri, Bantul District
}

\author{
Prihatin Saraswati ${ }^{1}$, Farah Najwa Ahmad Puad ${ }^{2 *}$ \\ ${ }^{1}$ Social Welfare Academy Akk Yogyakarta, Indonesia \\ ${ }^{2}$ Universiti Pendidikan Sultan Idris, Perak, Malaysia \\ *Corresponding email: farahnajwa@ftv.upsi.edu.my
}

Received: 02 April 2020; Accepted: 31 May 2020; Published: 03 June 2020

To cite this article (APA): Saraswati, P., \& Ahmad Puad, F. N. (2020). Development of touristic village and creative industry in improving social welfare at Wukirsari Village, Imogiri, Bantul District. Asian Journal of Assessment in Teaching and Learning, 10(1), 87-97. https://doi.org/10.37134/ajatel.vol10.1.10.2020

To link to this article: https://doi.org/10.37134/ajatel.vol10.1.10.2020

\begin{abstract}
The purpose of this study is to find out the role of development of touristic village and creative industry in improving social welfare on Wukirsari Village, Special Region of Yogyakarta Province (DIY Province). This research used qualitative and descriptive method. The data conveys that the development of touristic village and creative industry in Wukirsari Village brings out positive impact to its social welfare. The development consists of various productions; leather wayang puppet with tatah sungging, wedang uwuh traditional drink, bamboo crafts, and natural-dye batik. In addition, the village has distinct potentials to become a touristic village. Those distinct potentials are originated from its cultural resource, the Mataram kings' burial ground. The obstacles regarding this research were the coaching of better-quality touristic village development and creative industry people management in order to become a competitive travel destination.
\end{abstract}

Keywords: Touristic Village Development, Creative Industry, Social Welfare

\section{INTRODUCTION}

The diversity and richness of nature and culture are valuable potentials and opportunities to develop tourism sector in Indonesia so that it'll be more acknowledged and attractive in global perspective. Furthermore, it will also introduce characteristics of each region based on local potentials and wisdom (Ce, Timothy \& Chaozhi, 2020). Consequently, the government has an important role in digging up those potentials and making policies concerning tourism and creative industry development so that people will be moved to discover and develop their touristic village (Kubickova \& Martin, 2020; Agustina, Budhi, Utama \& Yasa, 2019). Currently, Indonesia has a tremendous prospect in tourism sector. Oka (2008) stated that Indonesia's prospect of tourism industry is huge and gratifying, remembering that tourism is a prime foreign exchange contributor to the country. Furthermore, the growth of tourism sector reaches up to $15 \%$ annually. Rural development growth fastens in Indonesia lead to opens new job offers, increases art, crafts, cultural output and broadens local industry market to go international.

Truong, Liu and Pham (2019) and Folarin and Adeniyi (2019) stated that tourism is an economic sector that's proven to be able to erase poverty in a region because in there must be a trickle-down effect for local people in the tourism management. Government's role in society empowerment regarding tourism is regulated in UU Number 10 Year 2009, a substitute of UU Number 9 Year 1990 about tourism. It is stated that the impacts from tourism development are the increasing of social welfare, decreasing poverty and unemployment rate, and preserving environment (Booyens, 2020; Gupta \& Dutta, 2019; Liu, Pan \& Zheng, 2019).

Evident effort that was done by the government since 2007 is declaring Visit Indonesia and promoting tourism destinations in Indonesia to international and local tourists. Since then, the development of touristic villages appear in Indonesia appears to the surface. One of them happens in DIY Province, a second national tourism destination right after Bali. DIY Province consists of 5 districts; Yogyakarta, Sleman, Kulonprogo, Bantul and Gunung Kidul. All of them compete to discover and develop 
their local potentials to launch touristic villages based on culture, nature or creative industry. This movement is supported by natural resources and local wisdoms in their own area.

The problem is, local potentials in developing a touristic village don't automatically lowers the number of poverties in the area. Badan Pusat Statistik (BPS) stated that by September 2013 the percentage of poverty reaches up to $15.03 \%$ of population in villages and cities. Furthermore, Kompasiana said that DIY Province is the poorest province in Java Island, though that statement is still debatable. BPS also stated that in the same year, $13.4 \%$ of population in Bantul district is in poverty. Therefore, the development of touristic village doesn't necessarily decrease poverty in the area. Wukirsari Village in Bantul District is one of many villages in DIY Province that develops its touristic aspects.

Wukirsari Village is located in the east side of Bantul. Approximately, it is $15 \mathrm{~km}^{2}$ wide and has 16 dusun and 91 RTs. The population is 14.000 with more than 1.500 population density per $\mathrm{km}^{2}$. This condition can be categorized as dense, just as other villages in the district. The labor force is up to 77,762 people, and the majority of them work in secondary sectors that support the development of their touristic village such as trade, service, private labor, etc. Wukirsari Village is one of 3 villages in Bantul District who won touristic village competition in 2014 held by Ministry of Tourism and Creative Economy.

Tourism and creative industry destinations in the village include:

1. Mataram kings' burial ground in Dusun Kedungbuweng

2. Sunan Cirebon burial ground in Dusun Cengkehan

3. Artist Saptohudoyo burial ground

4. Batik art in Dusun Giriloyo, Karangkulon, Cengkehan, and Kedungbuweng. This village became the pioneer of traditional hand-drawn batik in Bantul District

5. Tatah sungging in Dusun Pucung. Tatah sungging is a traditional craft, ranging from leather wayang puppet and other leather crafts

6. Bamboo crafts in Karangtalun, Jatirejo, Ndengkeng, and Nogosari II

7. Wedang uwuh traditional drink industry

From those, it can be concluded that Wukirsari Village has numbers of potential ranging from cultural, natural and economic tourism. Those potentials can be developed to give positive impact for opening new job offers in regards to improving local social welfare. However, compared to other tourism destinations in Bantul District, Wukirsari Village has not yet become the center of touristic attention unlike beach area that has high tourist demand. With taking those potentials into consideration, we were interested to carry out a research regarding the development of Wukirsari Touristic Village by delving existing local potentials and their impact to social welfare.

From the explanation above, the main problem in this research is to determine how far the development of touristic village and creative industry could give an impact to increasing social welfare. The purpose of this research is to describe government policies focusing on the strategies taken to develop touristic village in Wukirsari, the activities completed to develop existing craft industry potential and to find out the impact on the social welfare. The objective of this article is to find out the role of development of touristic village and creative industry in improving social welfare on Wukirsari Village, Special Region of Yogyakarta Province (DIY Province).

\section{Logical Framework}

Poverty in Indonesia mainly originates from rural area. This argument is supported by data from BPS, saying that in 2013, rural areas still dominantly contribute to poverty. $14.4 \%$ of poverty comes from rural areas, and only $8.52 \%$ comes from the cities. In the same year in Bantul, $13.4 \%$ of its population is in poverty. In Wukirsari alone, there are 4,882 poor people, or $29.23 \%$ of its population. The factors influencing poverty in rural areas are limited knowledge, education, and infrastructure, aside from nonoptimal human resource utilization. So that, poverty alleviation can be done by society empowerment. The empowerment refers to how the locals improve their lives socially and/or organizationally. 
Wukirsari Village has a collection of potentials, especially in tourism, which the specification belongs uniquely to Wukirsari alone. For example, the process of creating leather wayang puppet with tatah sungging technique, natural-dye batik, and historical heritage such as Mataram kings' burial ground. If those potentials are developed, then they are able to increase social welfare through potential mapping such as cultural, natural, and human resource and also social capital. In developing tourism potential, people have to provide accessibility, facilities, attractions, social institutions, and promotion so that it can boost local economy, increase labor force, and their income. Social welfare cannot be separated from social empowerment through touristic village that is synergized and coordinated with the local and/or central government. Said coordination is implemented through funding and training. This study logical framework is designed as presented in Figure 1.

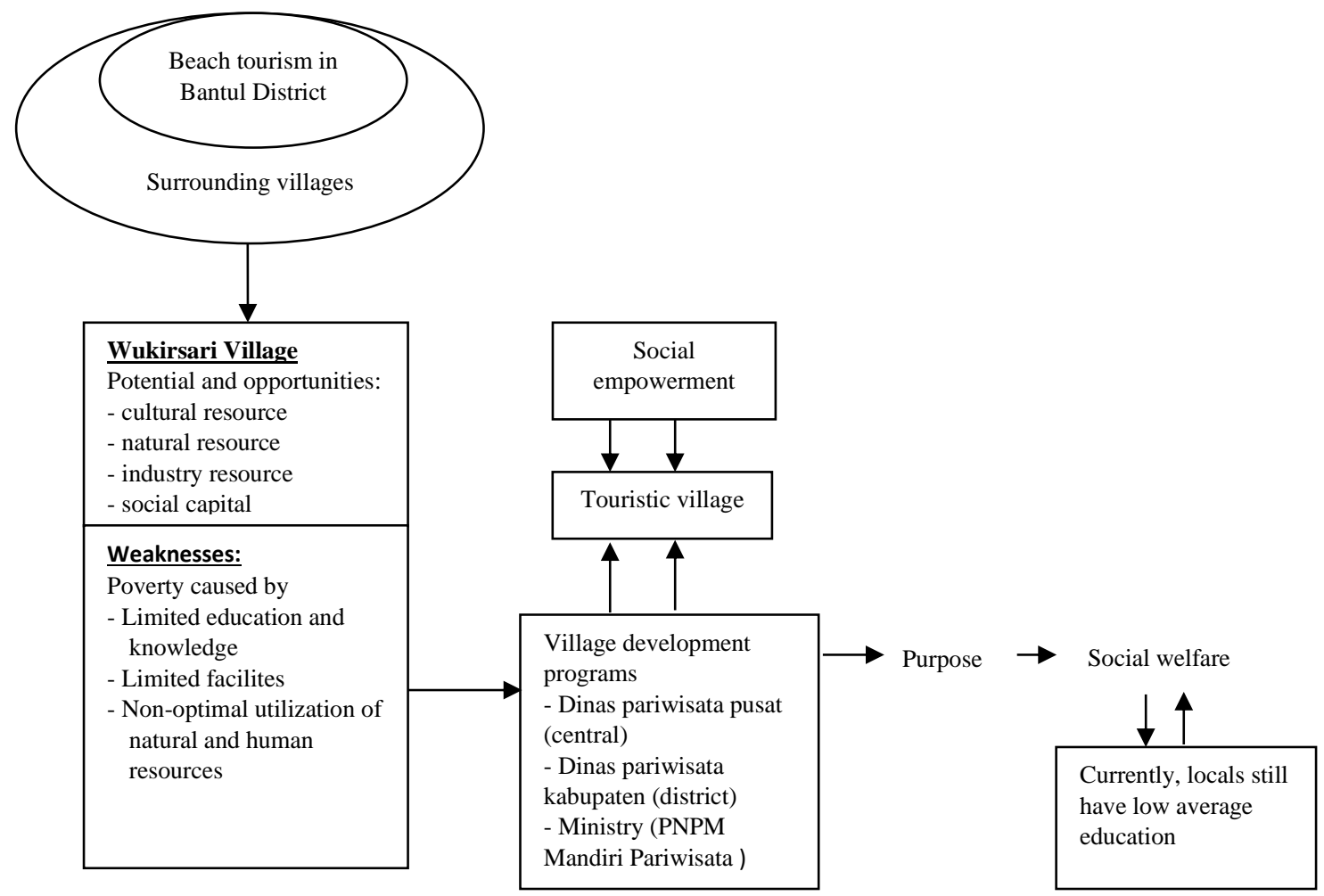

Figure 1. Logical Framework

\section{Concept Operationalization}

Social empowerment to improve social welfare through development of touristic village and creative industry will be easy to understand through these indicators as illustrated in Table 1 . There are three concepts that emphasized in this study which are poverty, touristic village and creative industry and social welfare. What is highlighted in poverty are economic aspect, job category, social aspect, formal and nonformal education, health facilities, bureaucracy and financial resources. There are five variables that are pointed out in touristic village and creative industry concept which are tourism attractions, cultural and natural attraction, type of craft industry, accessibility, facility, institution and marketing. Next, the variables that are highlighted in social welfare is locals' activities in providing tourism facilities and developing creative industry. 
Table 1. Research variables and indicators

\begin{tabular}{|c|c|c|}
\hline Concept & Variable & Indicator \\
\hline Poverty & $\begin{array}{l}\text { Economic aspect } \\
\text { - Family income or economy } \\
\text { - Chance to work } \\
\text { - Facilities and infrastructure } \\
\text { Job category } \\
\text { Social aspect } \\
\text { Formal and non-formal education } \\
\text { Health facilities } \\
\text { Bureaucracy and financial resources }\end{array}$ & $\begin{array}{l}\text { Main job } \\
\text { - Additional income } \\
\text { - Chance to work } \\
\text { - Infrastructure development, } \\
\text { - Phyisical development } \\
\text { Farmer, private worker, PNS, trade, creative } \\
\text { industry } \\
\text { Number of formal and non-formal education } \\
\text { graduate, skill training } \\
\text { Number of health facilities } \\
\text { Local government policies in villages, } \\
\text { Central government policies in villages, } \\
\text { Aid from other institutions }\end{array}$ \\
\hline $\begin{array}{l}\text { Touristic village } \\
\text { and creative } \\
\text { industry }\end{array}$ & $\begin{array}{l}\text { Tourism attractions } \\
\text { Cultural and natural attraction, type } \\
\text { of craft industry } \\
\text { Accessibility } \\
\text { Facility } \\
\text { Institution } \\
\text { Marketing }\end{array}$ & $\begin{array}{l}\text { Number and type of art being presented, cultural } \\
\text { attraction, natural tourism and crafts being } \\
\text { produced } \\
\text { Quality of access and transportation to go to the } \\
\text { destination } \\
\text { Type of tourism, business, service, hotel, } \\
\text { homestay, etc. } \\
\begin{array}{l}\text { Number and type of social institution in the } \\
\text { village related to tourism }\end{array} \\
\text { Number and type of promotion, social network, } \\
\text { and collaboration }\end{array}$ \\
\hline Social welfare & $\begin{array}{l}\text { Locals activities in providing tourism } \\
\text { facilities and developing creative } \\
\text { industry }\end{array}$ & $\begin{array}{l}\text { Number of locals involved in development } \\
\text { activities of touristic village such as providing } \\
\text { accommodation, attraction, food, local guide, and } \\
\text { creative industry }\end{array}$ \\
\hline
\end{tabular}

\section{METHODS}

This research was conducted in Wukirsari Village with qualitative and descriptive method. This study used in-depth interviews with 32 informants has been interviewed. The informants consist of one informant from Department of Culture and Tourism, five from tourism groups, four informants from creative industry groups, seven from guides or tour guides, ten tourists and 15 Wukirsari villagers. Primary data is generated from interview with ten informants namely Pokdarwis (Kelompok Sadar Wisata) which is from Department of Culture and Tourism, tourism groups and creative industry groups. Direct observation in the field also have been done in the data collection process. A group of tourists tour the tomb of the kings of Mataram, in an interview with the head of the POKDARWIS appointed by the palace of Yogyakarta, namely, Abdi Dalem Yogyakarta who knows the customs of managing the tomb of the kings of Mataram. This interview was conducted to find out the activities carried out in the care of the royal tombs, the procession of ceremonies that must be performed in accordance with the terms of the palace of Yogyakarta. Various tourist attractions, types of tourist arrivals, rules on tourist attractions and more.

The second group is group of breeding tourism developers and bird education. They were interviewed to know about programs such as breeding, bird species, care, cooperation with relevant agencies such as the Department of Environment, capital institutions, program activities, number of visitors, bird breeding management and more. Next is group of skin tourism tour developers with the 
technique of puppets which to know the product of puppets produced, movie raw material, manufacturing process, movie product management, tourist attraction, number of tourists and more. Other than that, we also interviewed a group of batik tourism developers with natural coloring to find out batik products produced, activities done, batik craft management, number of tourists and last bamboo craft tourism tour group. They are interviewed to get some information regarding what kind of product is produced, its management and others.

To strengthen the data collection, tourists are also interviewed randomly to find out the implications and suggestions regarding the developing of touristic village and creative industry in improving social welfare on Wukirsari Village. In addition, to find out if the Wukirsari village community has improved their well-being, Wukirsari villagers are also have been interviewed at random to find out the socio-economic situation before the tourist village was developing and after the tourism village was expanded including community income, community education, facilities and infrastructure. The interview had been conducted for two months to get the solid information from the informants. The data were analyzed by SWOT analysis. SWOT analysis is a tool to illustrate internal conditions (strengths and weaknesses) and external conditions (opportunities and threats), and in this research the topic that will be assessed with SWOT analysis is the development of touristic village and creative industry in Wukirsari Village.

\section{THEORETICAL BASIS}

Fandeli and Raharja (2012) conducted a case study in Pedusunan Tunggul Arum, Wonokerto, Turi, Sleman on potential and opportunity of rural area as a tourism attraction. Their SWOT analysis stated that the strengths include natural rural atmosphere, diversity of touristic village based on salak pondoh, historical heritage and locals' way of life. However, the weaknesses are the lack of infrastructure especially the entrance and local tourism center. The opportunity and threat are its closeness to forest and competition with other villages based on agrotourism. Other than that, Wijaya (2018) study shows saturation phenomenon of tourism which refers to mass tourism that ruins the environment and socialcultural aspect of the locals. To anticipate the negative impact from said mass tourism, then Wijaya proposed to develop alternative tourism located in Tenganan Pengringsingan. The location offers rice field panorama, historical buildings, rural atmosphere, traditional art, institutional and social systems. All of those are packed up as agro and cultural tourism.

Puja Astawa, Wirawan and Adhika (2005) also conducted a tourism research. They focused on integrated tourism development scheme, concentrating on social empowerment model in Central Bali which portrays unity of socio-culture and agrarian environment. Therefore, they established subak tourism as a hypothetical model for tourism development based on socio-culture and farming ecology potentials, which prioritize locals' contribution so that it'll increase social welfare. From the explanation above, it can be seen that development of touristic village has been conducted in lots of region. The end purpose of the development is to lower poverty rate and to increase its social welfare. This research will examine the development of touristic village and creative industry and its contribution in increasing social welfare. This topic goes hand in hand with Article 4 Undang-Undang Number 10 Year 2009 about tourism which stated that tourism's purpose is to a) increase economic growth, b) increase social welfare, c) eradicate poverty, d) resolve unemployment, e) preserve environment and natural resource, f) promote culture, $g$ ) promote the country's image, $h$ ) nourish love for the motherland, and i) strengthen international relations.

\section{Touristic Village Development}

Tourism sector development needs to be conducted continuously to encourage people to actively develop their area to achieve welfare. Tourism sector development is one of many activities that discover all potentials from an area which includes natural, human, cultural, and economic resources. If combined and managed well, those resources will give positive impact to social welfare. Tourism industry is a medium of agent of change through tourism. The essence of touristic village development is to determine how a village can grow as a tourism destination with attractions and education. Tourism sector development has huge potential to materialize social welfare (Marpaung, 49).

Furthermore, touristic village development planning can be done with community-based development approach. This approach implies that locals are the ones who carry out the development and manage the 
facilities with the result that they will receive direct economic incentive and prevent urbanization. The concept of touristic village translates as a rural area that can be utilized based on its capabilities regarding integrated tourism products. Said village offers a whole thematic atmosphere by portraying its rural authenticity in way of life, social, cultural, and economy with unique village layout, all of it packed as a series of tourism activities (Dirjen Pariwisata). Basically, touristic village accentuates local wisdom and culture, with local management utilizing existing nature, social, economy, historical, and layout potentials. Main components of a touristic village are:

1. Accommodation. Part of local housings develops with accommodation concept.

2. Attraction. All of locals' life and village physical environment enables integration with tourists as active participants. For example, batik, dance, language workshop, etc. that has specific aspect (http://jogja_ekotourism.blogspot.com, 2009).

If reviewed from tourism development by Purwodarminto (2012), a development means a process or a way to make something to become advanced, polished, perfect and useful. Next, Oka (2006) emphasizes that a product development basically is an effort conducted consciously with plans to improve current product and add product output that will be launched into the market. Touristic village development has to create an excellent product. Some of the characteristics are:

1. The object has attractiveness that could be enjoyed and learnt

2. It has a unique value

3. Available tourism facilities

4. Available accommodation, telecommunication and transportation

Tourism object development basically consists of these aspects:

1. Tourism product coaching

Is An effort to improve quality of service, accommodation, souvenirs, transportation, attraction, tour, travel, and tourism object. This coaching is done by combination of activities such as education, training, along with policy adjustment and briefing. The coaching encourages people to create a healthy competition environment and to improve quality of product and service.

2. Tourism society coaching

The purpose:

a) Encourage positive social potential preservation, both directly and indirectly to improve tourism

b) Reduce negative impact of tourism development

c) Collaboration coaching regarding tourism product, marketing and society

3. Integrated marketing

Tourism marketing uses integrated marketing principles including coherence product such as art and cultural attraction, hotels and restaurants that need to be developed so it could compete with other tourism products.

4. Integrated distribution

Transporting tourists to destinations through travel and transportation agencies, both through land route or airway and operators.

5. Integrated communication

A touristic village needs a good communication service to inform its product well. 
6. Integrated service

Good service means good tourism. Yati (2006) said that to develop an area as a tourism destination, it needs to meet 3 requirements:

a) The area needs to have a unique attraction (Something to see)

b) The area needs to have recreational facilities that could convince tourists to stay longer (Something to do)

c) The area needs to have stores, especially the ones who sell souvenirs and local crafts

Those three requirements are in line with the purpose of tourism marketing scheme: to get lots of tourists to come and stay longer through promotion, so that it'll increase money circulation in the area.

The concept of social welfare through development of touristic village and creative industry began in 1990 's. This concept was built to give positive impact to people, especially the ones in rural area around tourism objects. This concept is explained in the Figure 2.

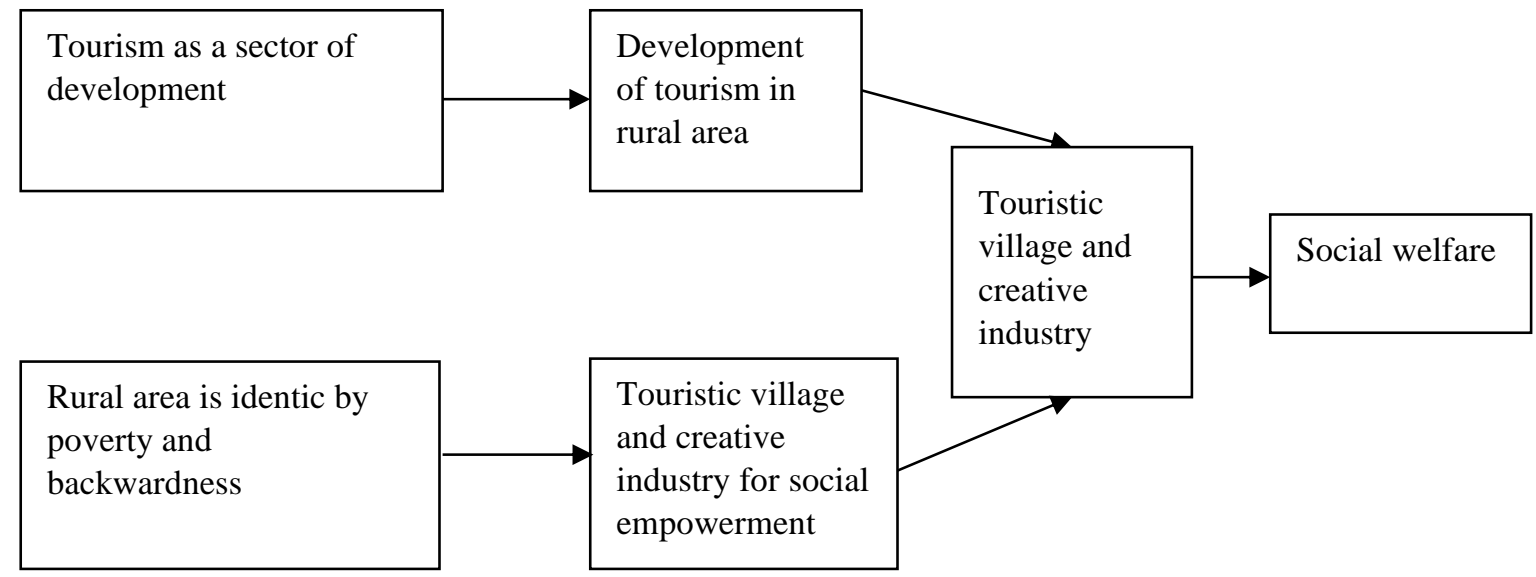

Figure 2. The development of creative industry touristic village and social welfare concept

\section{Creative Industry}

The concept of creative industry translates as a creativity or a creative behavior toward taking on life competition in globalization era (Agung, 2015). The phenomenon of how the economy is developed in the direction of creative industry becomes an indication of aspiration optimism to support acceleration and expansion of economic development in Indonesia, to make Indonesia become a developed country (Ahmad Kamil, 2015). The research conducted by Astuti, Hutabarat, Darwanto, Hamid and Satria (20112015) resulted in a knowledge saying that creative industry will have a competitive advantage if it utilizes optimal information technology. Furthermore, a research by Jerusalem (2009) stated that creative industry product can compete with other products alike if it has high innovation and creativity. Based on United Nation Conference on Trade and Development (UNCTAD), creative economy is an economic concept that evolves around creative aspects that has potentials to generate economic growth and development, that prioritize creativity, idea, and human knowledge as economic drive.

\section{Social Welfare}

Based on UU Number 11 Year 2009, the concept of social welfare is a condition where material, spiritual, and social needs of every citizen are met, in order to achieve a decent life and be able to develop themselves and do their social functions. BPS (2012) said there are 5 indicators of family welfare level:

1. Family income

2. Family spending composition, compared to food and nonfood spending

3. Family education level

4. Family health

5. Housing and facilities condition 
Welfare can be measured from various aspects (Kolle in Bintarto, 1989):

1. Materialistic life quality (e.g house, food, etc.)

2. Physical life quality (e.g health, environment, etc.)

3. Mental life quality (e.g education facility, culture, etc.)

4. Spiritual life quality (e.g moral, ethics, etc.)

From that definition, it can be concluded that social welfare is activities done to improve human's quality of life in physical, mental, emotional, social, economic and spiritual aspects.

\section{RESULT AND DISCUSSION}

\section{Strength}

This study found that development of touristic village and creative industry in Wukirsari Village directly affects social welfare (trickle-down effect), especially to people around tourism objects. The SWOT analysis interpreted that people's readiness to participate and their will to develop the touristic village and creative industry. People from Dusun Pucungrejo sacrificed their land certificate in order to build a road leading to tourism object. They also work together to make bamboo crafts. People's readiness is also seen from their activities regarding batik and wayang industry such as holding out and developing their tourism attractions. Other than that, the main road is already in excellent condition and beautiful natural scenery that emphasizes rural farming atmosphere surrounded by hills, complete with Mataram kings' burial ground on top. It has unique tourism specification potential that is hard to be found in other places. The area is accessible and close to other tourism destination in Bantul District, especially the beaches.

Moreover, hospitable and creative people regarding tourism service, it has another concept of natural tourism development supported by DIY Province government. Said concept is bird tourism based on education. Wukirsari Village is the pioneer of wedang uwuh tradional drink industry. This drink originally was only consummated by the royal family when they were visiting the burial ground. People's commitment to continuously discover and develop their potentials that could be promoted as tourism object and used as creative industry development. Other than that, availability of supporting facilities; joglo houses, gazebo, and pendopos, used to hold tourism process, production, and attraction and so with availability of electricity that enables good internet and social media access to outside world.

\section{Weaknesses}

This SWOT analysis found that traditional way of life for some people causes facility and creative industry to be managed traditionally. Next, low average formal education seem difficulties in improving social welfare on Wukirsari Village. Other than that, innovation and development of tourism and creative industry also isn't modern yet. Early stage of natural resource management also seems to leads timeconsuming development and promotion activities. In addition, village layout is not yet be laid out orderly and not portrayed a tourism destination yet. It also leads problems to readiness of hotels, restaurants, craft gallery and communication facilities. Weak tourism management, limited collaboration and promotion with travel agencies are also the weaknesses that this study found in improving social welfare on Wukirsari Village. Moreover, this study also found that there is minimum number of human resources to manage a touristic village with modern approach and limited business capital to develop tourism activities and creative industry.

\section{Opportunities}

However, we found that Wukirsari Village get some funding from PNPM Mandiri tourism, Dinas Pariwisata Kabupaten and DIY Province and other donors such as bank CSR. So, that they have high chance in improving social welfare on Wukirsari Village. Next, current tourism trend is back to nature. So, it can be a tourism destination for tourists which will benefit the village through utilizing natural, cultural and hospitality resource. The development of touristic village encourages locals to be more creative and innovative in establishing attractions, productions, and tourism services including foreign 
language training.

Next, the evolving industry of batik, wayang, wedang uwuh, and bamboo crafts that enables locals to develop their souvenir production. The most visited attractions by international tourists are the production of wayang puppet and its shows, and the production of batik. Tourists came from France, Japan, Australia, Germany, the United State of America, etc. They are able to spread the words about Wukirsari Village and thus promoting the village tourism. Moreover, batik is officially listed in the representative list of the intangible cultural heritage of humanity by UNESCO. Wayang and keris are also listed in masterpieces of the oral and intangible cultural heritage of humanity by UNESCO. The fact above leads up to wide marketing opportunity to the world, especially since Wukirsari Village has those industry and tatah sungging specification with natural-dye. The availability of Mataram king burial ground opens up a chance to develop tourism attraction related to history, religion, tradition, and culture of Kraton Yogyakarta.

\section{Threats}

Even though there are lots of opportunities in improving social welfare on Wukirsari Village, study has found that in Bantul District, there are many other areas that also develop their own touristic villages with main specification in natural and cultural resource to attract tourists. The study also found that there is minimum coordination among tourism managers and the development synergy is not yet to be seen too. Even if industry doers in Wukirsari Village have joined koperasi (cooperative union), not all of them has performed good management. The price in products and/or souvenirs hasn't included labor cost into account. Others, the wayang puppet production only runs when the orders came in. The situation is caused by the increasing price of raw material. Therefore, they need management and bank intervention. Tourists in Bantul District still dominantly visit the beaches. Wukirsari Village needs broader promotion and marketing and last but not least the packaging of wedang uwuh drink and bamboo crafts is still unattractive and leads up to limited pricing.

\section{Solution Alternatives}

From the analysis above it can be pulled out that the main weakness in Wukirsari Touristic Village development is the people's low education (the majority of them only studies until junior high school). Education is the main pillar of developing current and future human resource. Therefore, Wukirsari Village government is expected to motivate young generation to study in higher education. The education can be formal or non-formal through local industry and tourism training. The development of a touristic village needs skilled workers on its management regarding tourism objects, attractions, facilities, and services. If this matter is performed, it will lead to trickle-down effect; the effect of which advanced tourism in Wukirsari Village inflicts smooth social empowerment and will end up in social welfare. Reviewed in the scope of utilization, the development of tourism needs to be expanded in order to distribute social empowerment in wider coverage.

\section{CONCLUSION AND RECOMMENDATION}

\section{Conclusion}

Wukirsari Village has lots of local potential to create a superior touristic village. Those potentials are cultural tourism, creative industry, and natural resources. The location is along the way to the infamous beaches. Integrated marketing will attract more tourists. Since batik and wayang are listed as cultural heritage by UNESCO, it is possible to promote those crafts in Wukirsari Village through festivals and exhibition. Since Wukirsari Village has been launched as a touristic village in 2008, lots of tourists have come to the village, especially to witness and learn the production of batik and leather wayang puppet. On average, 10.000 tourists come to the village annually and $10 \%$ of them are international tourists. Bird tourism based on education is still on development process. At first, social empowerment was conducted to preserve batik and wayang production. However, the next step is to present those crafts as main potentials in developing a touristic village with direct impact to the increasing social welfare. Before, wedang uwuh was only produced by people around the Mataram kings' burial ground. These days, people 
in Wukirsari produce and market the drink nationally. Social welfare increases along with the development of touristic village in Wukirsari. Even more so with the intervention of third parties such as Corporate Social Responsibility from Bank Central Asia and Bank Negara Indonesia.

\section{Recommendation}

In order to develop touristic village and empower its people, Wukirsari Village needs to the following things in the near future like improve human resource education, both formally and non-formally, especially training regarding tourism, collaborating with Dinas Kebudayaan and Pariwisata academies. Other than that, Wukirsari Village necessity to establish tourism products, tour guides with foreign language training and unique restaurant. Adding new tourism attractions to attract tourists also is a must in improving social welfare on Wukirsari Village. Hold training sessions on how to make more interesting souvenirs and its management, related to creative industry development. In addition, Wukirsari Village also needs to hold training sessions on how to manage and utilize natural potentials to develop "back to nature" tourism. Broaden its marketing through coordination with various parties from the government to private parties and broaden its collaboration network with various parties regarding funding and training are also a must in making the Wukirsari Village as a tourist destination. Last, Wukirsari Village needs to hold training sessions to young generation on how to intensify their love to existing cultural heritage.

\section{REFERENCES}

Abdur Rohim. (2013). Pemberdayaan Masyarakat Melalui Pengembangan Desa Wisata (Studi Di Desa Wisata Bejiharjo, Kecamatan Karangmojo, Kabupaten Gunungkidul, DIY). Skripsi Thesis, Uin Sunan Kalijaga.

Agustina, M. D. P., Budhi M. K.S., Utama M. S. \& Yasa I. G.W. M. (2019). The influence of government role, community participation and social capital on the quality of destination and community welfare in the tourism village of Bandung Regency Province of Bali. RJOAS, 8 (92), 235-251.

Booyens, I. (2020). Education and skills in tourism: Implications for youth employment in South Africa. Journal Development Southern Africa. 1-13.

Ce, Timothy, D. J. \& Chaozhi, Z. (2019) Does tourism erode or prosper culture? Evidence from the Tibetan ethnic area of Sichuan Province, China. Journal of Tourism and Cultural Change, 17:4, 526-543.

Ditjen Pariwisata, 1999, Pengembangan Pariwisata Berbasis Masyarakat dalam rangka Pemberdayaan Ekonomi Rakyat, Jakarta

Edi Suharto (2011). Membangun Masyarakat Memberdayakan Rakyat, Bandung, Refika Aditama.

Fandeli \& Raharja (2012). Potensi dan peluang kawasan pedesaan sebagai daya tarik wisata, studi kasus di pedusunan Tunggal arum, Wonokerto, Turi, Sleman (potential and opportunity of rural area as a tourism attraction, a case study in Pedusunan Tunggul Arum, Wonokerto, Turi, Sleman)

Folarin, O. \& Adeniyi, O. (2019). Does tourism reduce poverty in Sub-Saharan African Countries? Journal of Travel Research, 59 (1), 140-155.

Freddy Rangkuti (1997). Analisis SWOT Teknik Membedah Kasus Bisnis, Jakarta, PT. Gramedia Pustaka Utama.

Gupta, M. R. \& Dutta, P. B. (2019). Efficiency wage, unemployment and tourism development: a theoretical analysis. Indian Growth and Development Review, 12 (3), 333-349.

Happy Marpaung (2010). Pengetahuan Kepariwisataan, Bandung, Alfabeta.

Jerusalem. (2009). Perancangan Industri Kreatif Bidang Fashion dengan Pendekatan Benchmarking pada Queensland's Creative Industry, Seminar Nasional Program Studi Tekni Busana, Yogyakarta, UNY Press.

Kamil A. (2015). Industri Kreatif Indonesia Pendekatan Analisis Kinerja Industri Jurnal Media Trend, 10 (2), $165-$ 182.

Kubickova, M. \& Martin, D. (2020). Exploring the relationship between government and destination competitiveness: The TALC model perspective. Tourism Management, 78, 104040.

Lely J. Maleong (2012), Metode Penelitian Kualitatif, Bandung, PT. Remaja Rosdakarya.

Liu, J., Pan, H. Zheng, S. (2019). Tourism Development, Environment and Policies: Differences between Domestic and International Tourists. Journals Sustainability, 11 (5), 1-15.

Mardi Yatmo Hutomo (2010). Pemberdayaan Masyarakat dalam Bidang Ekonomi Tinjauan Teoritis Dan Implementasi, Jakarta Bapenas.

Miftachul Huda (2009). Pekerjaan Sosial dan Kesejahteraan Sosial, sebuah pengantar, Yogyakarta, Pustaka Pelajar. Ndraha Taliziduhu (2003). Ilmu Pemerintahan Baru, Jakarta, Direksi Cipta.

Oka, A. Y. (2008). Ekonomi Pariwisata. Introduksi. Informasi. Implementasi. Kompas: Jakarta, Gramedia.

Parikesit, Sambojo (2006). Pengembangan Pariwisata Berbasis Pemberdayaan Masyarakat, Presentasi Dalam Rangka Persiapan Forum Koordinasi Lintas Sektor Dan Daerah Dalam Pemberdayaan Masyarakat Melalui Pengembangan Pariwisata Tanggal 9 Oktober 2006 Departemen Kebudayaan Dan Pariwisata. 
Puja Astawa I. B. G., Wirawan, I. G. P. \& Adhika, I. M. (2005). Pariwisata Terpadu: Alternatif Model Pengembangan Pariwisata Bali Tengah. Jurnal Denpasar: Universitas Udayana.

Sri Agustinus \& Wahyuni. (1996). Menejemen Strategi, Pengantar, Proses Berpikir Strategik, Jakarta, Binarupa Aksara.

Truong, V. D., Liu, X. \& Pham, Q. (2019). To be or not to be formal? Rickshaw drivers' perspectives on tourism and poverty. Journal Journal of Sustainable Tourism, 28 (1), 1-18.

Wijaya, A. A. G. (2014). Strategi pengembangan objek wisata desa tenganan pegringsingan kabupaten karangasem. Jurnal Ilmiah Hospitality Management, 4 (2), 25 - 40. 